\title{
THE EFFECTIVENESS OF INSTAGRAM AS A PROMOTION MEDIA AT CITRA ANANDA MATERNAL AND CHILD HEALTH HOSPITAL, CIPUTAT, BANTEN
}

\author{
Lili Marliani, Anhari Achadi
}

Faculty of Public Health, Universitas Indonesia

\begin{abstract}
Background: As the number of hospitals in Indonesia increased to 2,820 hospitals currently, so increases the need for marketing strategy. In this millennial era, there is a shift in marketing from traditional to digital marketing. A promotion through social media, especially Instagram has become an interesting choice. This study aimed to determine the effectiveness of Instagram as a promotion media at Citra Ananda Maternal and Child Health Hospital, Ciputat, Banten.

Subjects and Method: This was a quantitative study. Outpatients who followed the Instagram of Citra Ananda Maternal and Child Hospital were selected for this study. The independent variable was Instagram. The dependent variables included Aware, Appeal, Ask, Action, and Advocate (5A). The data were calculated using Purchase Action Ratio (PAR) and Brand Advocacy Ratio (BAR). The data were calculated based on the criteria of $5 \mathrm{~A}$. The data were analyzed descriptively.

Results: The percentage value in the Aware (X1) stage was 80.95\%, Appeal (X2) was 75.93\%, Ask (X3) was $82.82 \%$, Act $\left(\mathrm{X}_{4}\right)$ was $80.19 \%$, and Advocate ( $\left.\mathrm{X}_{5}\right)$ was $82.57 \%$. The conversion rate from Aware to Appeal was 0.94. Appeal to Ask was 1.09. Ask to Act was 0.97. Act to Advocate was 1.03. PAR value was 0.99 and BAR value was 1.02. The rate of conversion from Aware to Appeal showed that customer interest was high. Aware to Ask the information provided in the promotion was unclear. Ask to Act showed a high level of commitment from the customer. Act to Advocate showed a high level of affinity from the customer.
\end{abstract}

Conclusion: Instagram has substantial effects on Aware, Appeal, Ask, Act, and Advocate attributes of a promotional media at Citra Ananda Maternal and Child Hospital.

Keywords: effectiveness, social media, instagram, promotion, hospital

\section{Correspondence:}

Lili Marliani. Faculty of Public Health, Universitas Indonesia, Depok, West Java, Indonesia. Email: Liliamarlia.lm@gmail.com. Mobile: 085774261769.

\section{BACKGROUND}

The hospital is a health service facility that can meet one's health needs. With the increasing need and awareness of people for health, the number of hospitals has also increased. The increase in hospitals in Indonesia is classified as rapid. Based on data taken from the Ministry of Health in March 2019 the number of hospitals in Indonesia is 2,820 hospitals, consisting of 1.572 public hospitals and 1.248 private hospitals (Trisnantoro and Listyani, 2018).

The number of hospitals that are not small, making the community will increasingly have the freedom to choose a hospital that is believed to provide the best service.
This has led to increased competition in the hospital industry. In order to survive in this industry, business people in the hospital sector must be more creative and innovative in implementing marketing strategies in order to survive amid intense competition.

Marketing is an activity where a company tries to offer and sell an item or service to consumers so that the company makes a profit and consumers get the goods or services they need. Marketers must be skilled at creating public perception so that they are interested in making purchases of goods and services offered (Cendani, 2017).

In the marketing mix there is a set of marketing tools known as $4 \mathrm{p}$ marketing mix, 
namely product, price, place, promotion. Whereas marketing services have several additional marketing tools such as people, physical evidence, and process. Hence, it is known as the $7 \mathrm{p}$ marketing mix.

The seven elements of the marketing mix are interrelated and influential with each other. So, efforts must be made to produce a marketing policy that leads to effective service and customer satisfaction. In the hospital business which is a service provider business, there are seven important elements $\left.{ }_{7} \mathrm{P}\right)$ which are a collection of marketing tools that are interconnected and influential with each other. Therefore, the desired objectives can be achieved such as adding consumers. In this case, it is the patients who buy services that are offered by the hospital.

The internet has become strategic not only because of its sophistication, but also because of its extraordinary level of accessibility. The internet has now penetrated the age and geographical limits. The development of the number of internet users is increasing day by day. It becomes something that must be considered for anyone who has political interests (Tabroni, 2012).

In today's millennial era, there is a shift from traditional marketing to digital, known as marketing 4.0. Marketing 4.0 is an online and offline approach between companies and customers. Combining style with substance in building a brand and finally completing machine to machine connectivity with a human-to-human touch to strengthen customer engagement. Marketing 4.0 helps marketers switch to digital economics which is redefining key concepts of marketing (Kotler et al., 2014).

The concept of promotion has developed in recent years. Traditionally, promotion has always been a one-sided affair where companies send messages to customers as audiences. The rise of social media allows customers to respond to these messages. This also allows the customer to talk about the messages with other customers. Digital marketing is not intended to replace traditional marketing.

Instead, the two must coexist with roles that are exchanging along the customer's path. One of the earliest and most widely used frameworks to describe customer pathways is AIDA (attention, interest, desire, action).

Derek Rucker from Kellogg School of Management, offers a modification of AIDA called 4A (Aware, Attitude, Act, and Act again) (Kotler et al., 2014).

In the digital era or connectivity changes in the customer's path according to the changes formed by connectivity. In this era, the customer path is rewritten as $5 \mathrm{~A}$, namely: 1) Aware, at this stage the customer is passively exposed to a long list of brands from past experience, marketing communications, and/ or advice from others. Company-driven advertisements and word of mouth by other customers are also sources of brand awareness; 2) Appeal, in a highly competitive industry, brand appeal must be stronger. Some customers respond more to brand appeal than others. An example is young people are usually the first group to respond; 3) Ask, at this stage the customer usually follows up by actively researching brands that are of interest to them to get a lot of information from friends and family, the media, and/ or directly from the brand; 4) Act, if you feel confident with further information in the questioning stage, the customer will decide to act. The customer's desired actions are not just limited to purchases. After purchasing a brand, customers interact more deeply through consumption and use and post-purchase services; 5) Advocate, in this stage there are 3 levels of consumer loyalty. Level 1 is if consumers continue to use that brand called retention. Level 2, if the consumer makes a repurchase called repur- 
chase. The highest level is when consumers are willing to risk their personal reputation to recommend the brand. This stage is called loyalty which is the same as advocacy (Tampi and Pamungkas, 2018).

Citra Ananda Ciputat Maternal and Child Health Hospital has been using Instagram social media as a promotional media since January 2015. The Instagram account of Citra Ananda Ciputat currently Maternal and Child Health Hospital has 4,387 followers. Many new products or services owned by Citra Ananda Ciputat Maternal and Child Health Hospital are delivered to the public through Instagram in the hope that they will get good feedback by selling these products to the public and increasing the number of patient visits.

Since actively using social media Instagram in January 2015, there has been a significant increase in the number of Ananda Ciputat Maternal and Child Health Hospital patient visits, especially the number of outpatient visits. Citra Ananda Ciputat Maternal and Child Health Hospital is a special type $\mathrm{C}$ hospital which has only been operating for around 7 years. Special hospital located in the city of South Tangerang which already has 27 hospitals (Ministry of Health, 2019). How small hospital can survive to achieve its mission is certainly largely determined by how the marketing strategy chosen by the management.

The seven important elements mentioned above must really be applied in order to obtain maximum results. Promotion is one important aspect that is crucial. How to get Citra Ananda Ciputat Maternal and Child Health Hospital to survive among its competitors is the promotion method that must be applied must pay attention to the times and society with all its demands. Based on these considerations, Citra Ananda Ciputat Maternal and Child Health Hospital made social media Instagram as a promotional media.
The extent to which the effectiveness of social media called instagram as a promotional media is unknown. This is the reason for the author to conduct a study on how the effectiveness of Instagram as a promotional media at Citra Ananda Ciputat Maternal and Child Health Hospital.

The effectiveness of Instagram as a promotional media in Citra Ananda Ciputat Maternal and Child Health Hospital will be evaluated using the Marketing Productivity Purchase Action Ratio (PAR) and Brand Advocacy Ratio (BAR) metrics. They are metrics to measure the productivity of a promotional strategy. Both of these metrics are in line with $5 \mathrm{~A}$. PAR is a metric to measure how well companies convert awareness of a brand into purchases. Whereas Brand Advocacy Ratio (BAR) is a metric to measure how good companies convert brand awareness into brand advocacy (Kotler et al., 2014).

\section{SUCJECTS AND METHOD}

\section{Study Design}

This was a descriptive quantitative study. The statistical analysis used was quantitative descriptive analysis by describing in detail the problem being examined based on the data obtained. Data were obtained through questionnaires that had been filled by respondents.

The location of the study was conducted at RSIA Citra Ananda, South Tangerang City, Banten. The study was conducted in JulySeptember 2019.

\section{Population and Sample}

The population in this study was Instagram followers of Citra Ananda Ciputat Maternal and Child Health Hospital with the sampling technique used was random sampling. The selected sample was outpatients who follow the Instagram account of Citra Ananda Ciputat Maternal and Child Health Hospital who came in the study period that met the inclusion criteria. A total of 98 people was 
selected for this study using Slovin formula.

\section{Variable of the Study}

The dependent variable in this study was Instagram. The independent variables in this study were Aware, Appeal, Ask, Action, and Advocate (5A).

\section{Operational Variables}

Aware (X1) was the awareness of Citra Ananda's Maternal and Child Health Hospital instagram account followers about Citra Ananda's Maternal and Child Health Hospital promotions on Instagram.

Appeal (X2) was the interest of Citra Ananda Maternal and Child Health Hospital's instagram followers for promotions in Citra Ananda Maternal and Child Health Hospital's Instagram account.

Ask (X3) was Citra Ananda Maternal and Child Health Hospital's Instagram followers who will ask about promotions in Citra Ananda's Instagram account.

Act (X4) was an Instagram followers of Citra Ananda Maternal and Child Health Hospital who come to Citra Ananda Maternal and Child Health Hospital for promotions on their Instagram accounts.

Advocate (X5) was followers of Citra Ananda Maternal and Child Health Hospital's instagram account who will encourage friends or relatives to go to Citra Ananda Maternal and Child Health Hospital.

\section{Study Instruments}

The data were collected through questionnaires survey by visiting respondents.

\section{Inclusion and Exclusion Criteria}

The inclusion criteria used were new adult patients who came to outpatient treatment and parents of new pediatric patients who came to outpatient treatment.

The exclusion criteria were emergency patients, long-time outpatients, and new outpatients who did not follow the instagram account of Citra Ananda Ciputat Maternal and Child Health Hospital.

\section{Data Analysis}

Analysis of the data used is quantitative descriptive data analysis by describing in detail. Data obtained through a questionnaire was used to find out the indicators of $5 \mathrm{~A}$ (Aware, Appeal, Ask, Act, Advocate) which were the variables in measuring the effectiveness of the Instagram promotion media. In filling out the answers to the questionnaire, the answer 'strongly agree' gets a value of 4 , the answer 'agree' gets a value of 3 , the answer 'disagree' gets a value of 2 , and the answer 'strongly disagree' gets a value of 1 .

The data obtained is then analyzed by calculating the total the answer. From these data, the percentage of each indicator is calculated using the following formula:

$$
\begin{aligned}
& \text { Xn: } \quad \frac{\text { Total value of } x \mathrm{n}}{\text { Total expectation value }} \times 100 \% \\
& \text { Xn: } 4 \times 3 \times 98=1.176
\end{aligned}
$$

Information:

$\mathrm{Xn}$ : The value of variable $\mathrm{n}$

$\mathrm{X} 1$ : The value of Aware variable

X2: Value of Appeal variable

$\mathrm{X}_{3}$ : Value of Ask variable

$\mathrm{X}_{4}$ : Value of Act variable

$\mathrm{X}_{5}$ : Value of Advocate variable

To strengthen the results of the study, PAR (Purchase Action Ratio) and BAR (Brand Advocacy Ratio) measurements were calculated based on the $5 \mathrm{~A}$ criteria after the conversion rate of each variable was also calculated.

\section{RESULT}

\section{The Overview of the Respondents}

Respondents in this study were 98 people who represented the followers of Citra Ananda Maternal and Child Health Hospital's Instagram account who came to Citra Ananda Maternal and Child Health Hospital at the time of the study. The number 
of respondents was 98 people consisting of 90 women and 8 men. If classified in the age group, there were 9 people aged between 2125 years, 47 people aged between 26-30 years, 28 people aged between 31-35 years, 12 people aged between 36-40 years, and 2 people aged between 41- 45 years old. Based on education level, there were 2 people with Junior High School education, 13 people with Senior High School education, 19 people with Third level associate's degree education level, 60 people with bachelor degree, and 4 people with Masters education. Based on his work, there were 34 people who were housewives, 43 were private employees, 4 were civil servants, and 20 were entrepreneurs.

\section{Percentage of 5 A Variable}

Based on data obtained from filling out the questionnaires by the respondents, obtained several calculation results as follows:

1. Percentage Value in Aware Stage (X1)

$952 \times 100 \%$

1176

$=80.95 \%$

2. Percentage Value in Appeal Stage (X2) $\underline{893} \times 100 \%$

1176

$=75.93 \%$

3. Percentage Value in Ask Stage (X3)

$974 \times 100 \%$

1176

$=82.82 \%$

4. Percentage Value in Act Stage (X4)

$943 \times 100 \%$

1176

$=80.19 \%$

5. Percentage Value in Advocate Stage $\left(\mathrm{X}_{5}\right)$

$971 \times 100 \%$

1176

$=82.57 \%$

3. The level of effectiveness of the Instagram account of Citra Ananda Maternal and Child Health Hospital as a Promotion Media

1. Conversion rate from aware to interes- ted:

$\underline{\text { Appeal }}=\underline{893}=0.94$

Aware 952

2. Conversion rate from interested to asking:

Ask $=974=1.09$

Appeal 893

3. Conversion rate from asking to acting:

$$
\underline{\text { Act }}=943=0.97
$$

Ask 974

4. Conversion rate from acting to advocating:

$$
\frac{\text { Advocate }}{\text { Act }}=\frac{971}{943}=1.03
$$

5. Instagram Effectiveness as a Media Promotion seen from PAR (Purchase Action Ratio)

$$
\begin{aligned}
& \mathrm{PAR}=\frac{\text { Act }}{\text { Aware }}=\frac{943}{952}=0.99 \\
& \mathrm{BAR}=\frac{\text { Advocate }}{\text { Aware }}=\frac{971}{952}=1.02
\end{aligned}
$$

\section{DISCUSSION}

From the general description of respondents it is known that the majority of customers or patients of Citra Ananda Maternal and Child Health Hospital were women with an age group between 26-30 years. The highest level of education was bachelor degree. Most jobs were private employees.

The general description of respondents representing hospital customers who are the followers of the Ananda Maternal and Child Health Hospital insagram account is a millennial group with high level of education and a job with sufficient income.

From the calculation results, there was a fairly high response from the Instagram account of Ananda Maternal and Child Health Hospital followers for each variable $5 \mathrm{~A}$. The highest response is in the ask and advocate variables. This indicates that there is a high curiosity from followers of the Citra Ananda Maternal and Child Health Hospital Instagram account to information obtained 
on the Citra Ananda Maternal and Child Health Hospital Instagram account and the high level of loyalty or encouragement from customers or patients of Citra Ananda Maternal and Child Health Hospital.

In marketing, curiosity arises when customers are given interesting knowledge without being given too much information. To take advantage of curiosity, marketers must create content that can be searched and shared whenever customers search for it (Kotler et al., 2014).

It should be noted that lack of information can make information conveyed unclear and cannot be captured by customers. Marketers with a long-term orientation view sales as the beginning of a more useful relationship. When experience actually meets or exceeds expectations, customers will develop a sense of affinity and are more likely to be loyal advocates (Kotler et al., 2014).

The high value of Advocate variable indicates that Citra Ananda Maternal and Child Health Hospital customers have high affinity which means Citra Ananda Maternal and Child Health Hospital can build longterm relationships with its customers. PAR and BAR are metric to measure the effectiveness of a company promotion. PAR measures how well a company converts brand awareness into purchases. Whereas BAR measures how a company converts brand awareness into brand advocacy. The ideal BAR score is close to 1 . which means every customer who is aware of the existence of a brand, finally recommends that brand (Kotler et al., 2014).

Advocate values higher than Act can occur in hospital health services. This is because even if a customer likes the service product at the hospital, if it is not needed, certainly they will not come for treatment. However, customer loyalty can be seen from the high value of advocate (advocating for people who need services).

Since 2015, there has been ask-advocate connectivity between customers who ask questions and customers who answer with recommendations but this connectivity has not been balanced. Often more people ask questions than those who recommend a brand. The direction of this connectivity will change both if the brand is recommended positively and will change badly if the brand is recommended negatively (Tampi and Pamungkas, 2018).

Citra Ananda Maternal and Child Health Hospital customers have higher advocate value than the ask value. This indicates a high advocacy value that can be positive and turn into a purchase (act) if recommended positive. The PAR value measured through the indicators contained in variable $5 \mathrm{~A}$ approaches 1 (0.99), which indicates that of the 952 people who were aware of advertisements on the Citra Ananda Maternal and Child Health Hospital Instagram account, 943 people came for treatment at Citra Ananda Maternal and Child Health Hospital (99\%).

Instagram is an effective promotional media because its BAR value exceeds 1(1.02). This means that all customers of Citra Ananda Maternal and Child Health Hospital who are aware of service advertisements on Instagram will encourage them to come to Citra Ananda Maternal and Child Health Hospital to their friends or relatives even if they do not or have not come for treatment.

This study has a shortage because previously it has not been studied too much by other researchers considering the effectiveness and productivity theories measured using PAR and BAR metrics are still new. So, it needs to be further investigated by other researchers using a larger sample and a longer time.

From these results it can be seen that the response of Citra Ananda Maternal and Child Health Hospital customers to the promotion on the Citra Ananda Maternal and 
Child Health Hospital Instagram account is quite good. Also, promotion through social media is an effective promotion in increasing the number of new patients and retaining old patients. The hospital management can continue to increase promotion through Instagram.

\section{REFERENCES}

Cendani TP (2017). Pengaruh marketing mix 7 P terhadap keputusan pembelian layanan jasa laundry sepatu (studi pada Glow Shoes Care). Indonesia Membangun, 2(1): 1-15

Kotler P, Kartajaya H, Setiawan I (2014). Marketing 4.o. Bergerak dari tradisional ke digital. Edited by A. Tarigan. PT Gramedia Pustaka Utama.

Ministry of Health (2019). Data RS Online. Retrieved from http://sirs.yankes.kemkes.go.id/f/

Prihatiningsih W (2017). Motif penggunaan media sosial Instagram di kalangan remaja. Communication, 8 (1): 51-65.

Sedarmayanti, Hidayat S (2011). Metodologi penelitian, Bandung.

Tabroni R (2012). Komunikasi politik pada era multimedia. Edited by NS Nurbaya, Bandung: Simbiosa Rekatama Media.

Tampi EN, Pamungkas INA (2018). Analisis customer path $5 \mathrm{~A}$ pada sponsor film AADC 2 sebagai program entertaintment branding. Kajian Televisi dan Film, 2(1): 69-86

Trisnantoro L \& Listyani E (2018). Jumlah RS di Indonesia pertumbuhan RS publik. Retrieved from https://www.persi.or.id/images/2017/litbang/rsindonesia418.pdf

Ulfa M (2018). Efektivitas Instagram dalam mempromosikan penjualan kamar Batiqa Hotel Pekanbaru. JOM FISIP, 5(1): 1-14. 